\title{
The Carbon Footprint of Construction of Make-up Water Cooling System
}

\author{
Chawalit Chanamai*, Narin Phaowanich \\ Power Plant Engineering Division, Electricity Generating Authority of Thailand, Nontaburi, Thailand.
}

How to cite this paper: Chawalit Chanamai, Narin Phaowanich. (2021) The Carbon Footprint of Construction of Make-up Water Cooling System. OAJRC Environmental Science, 2(1), 1-6.

DOI: 10.26855/oajrces.2021.10.001

Received: September 3, 2021

Accepted: September 28, 2021

Published: October 25, 2021

*Corresponding author: Chawalit Chanamai, Power Plant Engineering Division, Electricity Generating Authority of Thailand, Nontaburi, Thailand.

Email: 594682@egat.co.th

\begin{abstract}
Recently, the international attention on environmental pollution. Population growth and economic growth are the main factor of power shortage and pollution problems. Reducing excessive emissions of greenhouse gas and climate change, carbon dioxide is favorite indicator to quantify emission pollutant in products or organization. Previous researches have focused on operational phase, while the construction industry is around one-third carbon emissions. Moreover, the previous studies estimated the carbon dioxide equivalent of the construction stage of the power plant was $1.54 \%$ of coal combustion. It is a challenge to reducing emission impact of the power plant. This research paper evaluates the carbon emissions during construction for a case study of construction of make-up water cooling system of the combined thermal power plant in Thailand. Carbon footprint was applied to estimate the carbon emissions. The amount of carbon equivalent were calculated according to the Life Cycle Assessment (LCA) method in three parts of construction: approach channel, cooling water intake pump house and cooling tower basin, which was the highest GHG emission part. The carbon footprint value of the construction of make-up water cooling system was $26,715.6 \mathrm{tCO}_{2} \mathrm{e}$ or $2.448 \mathrm{tCO}_{2}$ e per square meter.
\end{abstract}

\section{Keywords}

Carbon Footprint, Construction, Water Cooling System, Thermal Power Plant

\section{Introduction}

Global warming and climate change are the main problems concerning by many people. The major course of these problems is environment pollution being related to economic and population growth [1]. It is a challenge to find solutions for reducing intensified and devastating consequences on human survival and the environment. Thailand is one of the countries affected extreme weather events such as flood and drought. However, it needs all sectors help reducing greenhouse gas emissions. Thailand proposes a Nationally Determined Contribution (NDC) aiming to reduce greenhouse gas emissions by 20 to 25 percent by 2030 as enhances ambition of the Nationally Appropriate Mitigation Action (NAMA) ambitions [2-4].

The greenhouse gas (GHG) affects a wider area around the world such as climate change, flood, drought, health and biodiversity. GHG is consists of six major gas constituents including Carbon Dioxide $\left(\mathrm{CO}_{2}\right)$, Methane $\left(\mathrm{CH}_{4}\right)$, Nitrous Oxide $\left(\mathrm{N}_{2} \mathrm{O}\right)$, Hydrofluorocarbons (HFCs), Perfluorocarbons (PFCs) and Sulphur hexafluoride (SF $)_{6}$ [2, 5, 6]. United Nations Framework Convention on Climate Change (UNFCCC) guideline measuring products and activities of the greenhouse gas emission base on the equivalent in carbon dioxide [7]. The carbon footprint was developed and used as a tool to explain the amount of carbon dioxide that causes greenhouse gas emissions. It calculates the amount of greenhouse gas emissions in term of carbon dioxide into environment from operation, production and services [8]. The important factor of greenhouse gas effect is the construction industry sector that is around 40 percentage of the annual world's energy $[9,10]$. 
In 2016, Thailand emitted GHG less than 1 percentage of global emission (lower than world average). The energy sector was the main GHG emission around 71.65 percent of the total sources (387,357 $\mathrm{Gg} \mathrm{CO}_{2} \mathrm{e}$ ) [2]. According to the Thailand Power Development Plan 2018-2037, Carbon Dioxide emission from power generation between 2022 and 2037 will increase from 84,841 kt $\mathrm{CO}_{2} \mathrm{e} /$ year to 99,712 kt $\mathrm{CO}_{2} \mathrm{e} /$ year [4]. Thailand's Power Demand Forecast was calculated upon the average long-term GDP growth during year 2018-2038 estimated by the Office of National Economic and Social Development Council (ONESDC) of 3.80 percent per year and the average population growth of -0.02 percent per year. In 2038, the expected energy and power demand would be 367,458 GWh and 53,458 MW respectively [4]. That means the power plant need to construction to support the future requirement of power. The study about considered greenhouse gas emission in construction stage shall be improve the decision making for the selection of projects, the policies and plan strategies for infrastructure development towarding low carbon cities.

\section{Theoretical overview}

\subsection{Life Cycle Assessment (LCA)}

Nowadays, research on building carbon emissions has achieved some success with Life Cycle Assessment (LCA). LCA technique is a systematic assess of environmental impact providing information to understand the energy usage and various other environmental effects. The LCA method can be analyzed and quantify the environmental pollution of product, system and process [1, 11]. LCA method improves the environmental performance of the construction projects. The construction companies can evaluate and control GHG emission by selecting the optimal materials and construction processes [1].

Two types of LCA method is generally used to measure the environmental impact of product. There are Cradle-to-Grave (Business to Consumer, B2C) and Cradle-to-Gate (Business to Business, B2C) [5, 6]. B2C has four stages including materials production, construction, operation and maintenance, and end of life, while B2B consider only first 2 stages [10, 11]. This research focuses on the B2B model including the acquisition of raw materials, construction and installation without implementation and removal of the remains. The LCA of make-up water cooling system of $\mathrm{CO}_{2}$ emission is shown in Figure 1.

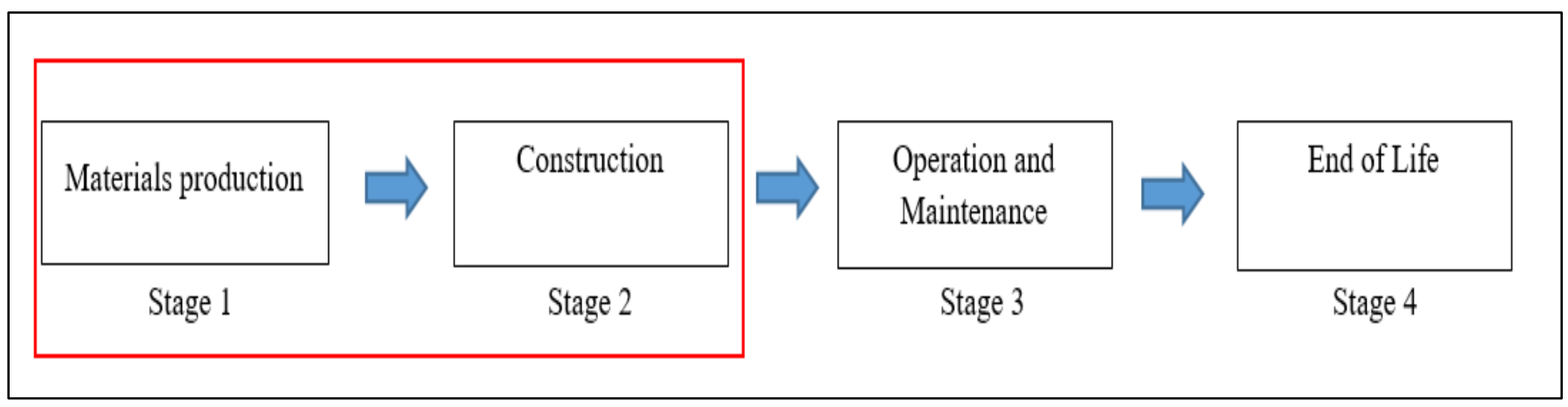

Figure 1. The four stage of Carbon Dioxide Emission of Construction.

\subsection{Carbon Footprint}

Carbon Footprint is used to comparison releasing greenhouse gas throughout the product life cycle.It is the process of measuring the amount of greenhouse gases emitted by all process of LCA including the raw material acquisition process, transportation, assembly or construction, operation, and post-use management of waste or end-of-life products. The calculation of carbon footprint analyses base on the form of carbon dioxide equivalents [5, 6]. Carbon footprint can estimate the amount of greenhouse gases emitted by the organization's activities and also identify the causes of significant greenhouse gas emissions and find ways to reduce the GHG emissions [7, 8]. It may use as carbon credits to set the standard of compensation of environment impacts with other organizations

The framework of the Greenhouse Gas Protocol classifies emissions as direct GHG emissions and indirect GHG emissions. The operational boundary of GHG accounting has three scopes of indirect GHG emissions proposing by the GHG Protocol. The majority of GHG emission of construction is considered in scopes three [1, 10]. Three scopes of emissions associate such as operation by people or business, materials, fuels, transport-related activities in vehicles, electricity-related activities and waste disposal $[5,8,9]$. This assessment is consistent with international standards such as the life cycle of the product ISO14040, assess the carbon footprint of products 2050:2011 and carbon footprint assessment guidelines of products made in Thailand by the Organization. After literature review, the list of data collection for calculation of GHG emission of construction was shown in Table 1. 
Table 1. Data Sources for Carbon Footprint Analysis of Construction

\begin{tabular}{cc}
\hline Items & Sources \\
Materials of construction & $\begin{array}{c}\text { Bill of quantities } \\
\text { Construction drawing } \\
\text { Mater consumption } \\
\text { Electric power use } \\
\text { Transportation distance } \\
\text { Emission Factor }\end{array}$ \\
Thai national database by TGO and IPCC [5, 6, 7, 12, 13] \\
Site construction \\
Site construction \\
Site construction and map \\
Thai national database by TGO [5, 6, 12] \\
IPCC [7]
\end{tabular}

The methodology of GHG emissions of cooling water system is proposed by the Intergovernmental Panel on Climate Change (IPCC) and Thailand Greenhouse Gas Management Organization (TGO) [5-7]. The estimating GHG emissions quantify following by the equation below.

$$
E=\sum_{a}\left(A D_{a} \times E F_{a}\right)
$$

Where $\mathrm{E}$ is the total carbon emission in the construction stage ( $\left.\mathrm{kg} \mathrm{CO}_{2} \mathrm{e}\right)$. AD is the activity data (unit of use). EF is the emission factor ( $\mathrm{kg} \mathrm{CO} \mathrm{CO}_{2}$ eper unit of use) and a is greenhouse gas emissions activities (e.g. fuel, energy etc.).

GHG emissions $\left(\mathrm{kg} \mathrm{CO}_{2} \mathrm{e}\right)$ associated with the use of material (Em), electricity consumption (Ep), water consumption (Ew) and fuel consumption of equipment (Ee) and fuel consumption of transport (Et) during the construction phase. The carbon impacts of materials were calculated for each construction material. The carbon emission of electricity consumption is calculated from the amount of electricity used by the construction site. It consists of electricity used in construction and electricity generated by construction workers multiplied by the emission factor of electricity. The concept of carbon emission of water consumption and wastewater drainage are the same as carbon emission of electricity consumption. The carbon impacts of fuel were considered from their transportation and their activities.

$$
\begin{aligned}
& E_{m}=\left[Q u a n t i t y\left(m^{3}\right) \times \operatorname{Density}\left(\frac{\text { kgmaterial }^{3}}{m^{3}}\right)\right] \times E F\left(\frac{\mathrm{kgCO}_{2} \mathrm{e}}{\text { ggmaterial }^{2}}\right) \\
& E_{e}=\left[F C R\left(\frac{\text { Lfuel }}{E q . h}\right) \times \text { Quantity }(E q) \times \operatorname{Duration}(h)\right] \times E F\left(\frac{\mathrm{kgCO}_{2} e}{\mathrm{kgLfuel}}\right) \\
& E_{t}=[\operatorname{Mass}(\text { kgtransported }) \times \operatorname{Distance}(\mathrm{km})] \times \operatorname{EF}\left(\frac{\mathrm{kgCO}_{2} e}{\text { kgtransported.km }_{\text {trans }}}\right) \\
& E_{p}=\text { Electricityconsumption }(k W h) \times E F\left(\frac{k g C O_{2}}{k W h}\right) \\
& E_{w}=\text { Waterconsumption }\left(\mathrm{m}^{3}\right) \times E F\left(\frac{\mathrm{kgCO}_{2}}{\mathrm{~m}^{3}}\right) \\
& E_{\text {waterpumping }}=\left[\operatorname{Power}\left(\frac{k W h}{\text { pump }}\right) \times \text { Quantity }(\text { pump }) \times \operatorname{Duration}\left(\frac{h}{y}\right)\right] \times E F\left(\frac{\mathrm{kgCO}_{2}}{\mathrm{kWh}}\right)
\end{aligned}
$$

where FCR is the fuel consumption rate.

\section{Study Area}

According to Thailand [2], the Bang Pakong Combined Cycle (Unit 1-2 Replacement) Project originated plan. The plan stipulated that Electricity Generating Authority of Thailand (EGAT) should develop the project to help meet demand for electricity and enhance system security of Thailand. It is therefore considered necessary to construction a new power plant to replace the existing old plant group in 2019 [3, 4].

Bang Pakong Combined Cycle (Unit 1-2 Replacement) is located 69 km southeast of Bangkok in Amphoe Bang Pakong, Chachoensao Province, Thailand. The power plant is on the left bank of Bang Pakong River, $11 \mathrm{~km}$ upstream of the Gulft of Thailand. Bang Pakong Combined Cycle (Unit 1-2 Replacement) was designed to be a combined cycle power plant with an installed project installed capacity of about 1,450 MW in case of using natural gas [14]. The area of construction was around $80,000 \mathrm{~m}^{2}$. Due to COVID-19 restrictions, the construction of Bang Pakong Combined Cycle (Unit 1-2 Replacement) was between January 2019 and January 2021.

This research studied the carbon footprint of make-up water cooling system of the combined thermal power plant in Thail- 
and. The boundary of study was divide three part of civil work; make-up water cooling system were approach channel and reservoir, cooling water intake pumping house and cooling water building without mechanical and electrical work (see Figure 2). The maximum capacity of water in make-up water cooling system is $10 \mathrm{~m}^{3} /$ day. Most of construction parts of make-up water cooling system were concrete and precast concrete. The cooling water intake pumping house only was built by concrete and steel structure. Due to COVID 19, the duration of the power plant construction was around 368 working days.

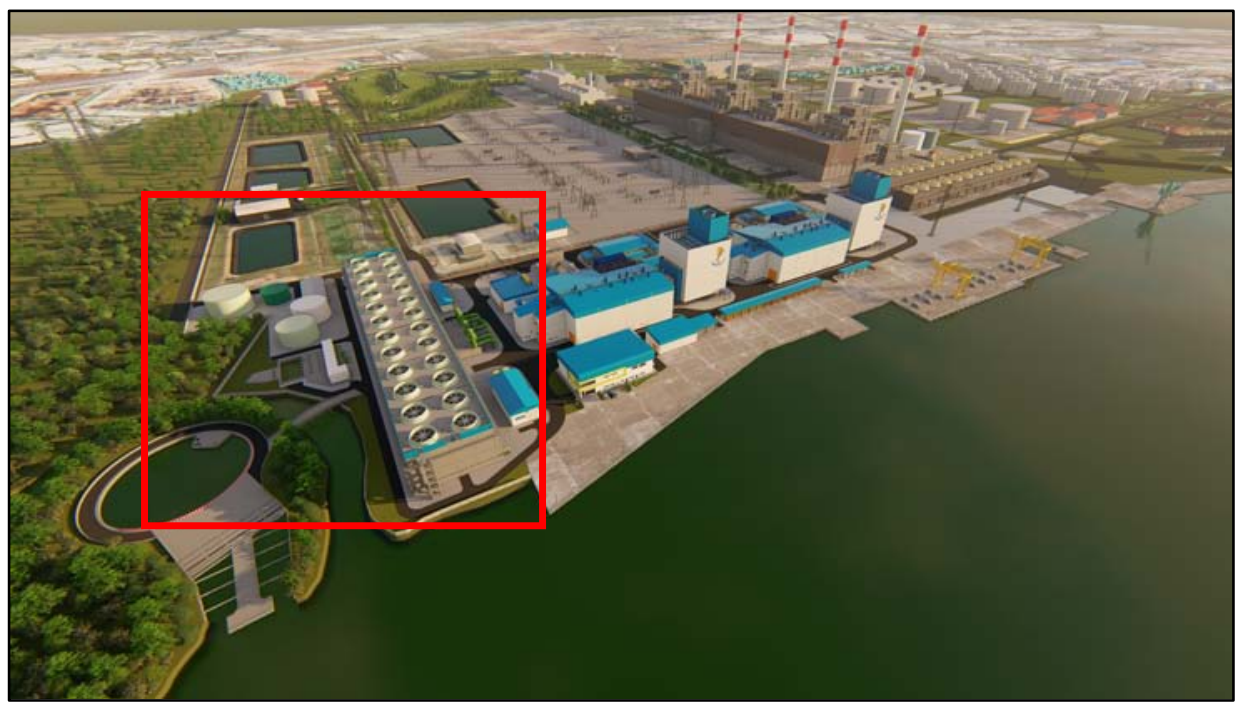

Figure 2. Study area.

\section{Results}

The estimation of carbon footprint emission of make-up water cooling system in construction phase was $126,715.6 \mathrm{tCO}_{2} \mathrm{e}$. The proportion of greenhouse gas emissions from make-up water was shown in Figure 3. The concrete and group of steel were the most emission extensive trades during the construction period, which account for $56.50 \%$ and $16.35 \%$ emissions respectively. The transportation was the third emission trades in construction phase, which was $13.92 \%$. While, electricity including office, dewatering and equipment was the small amount of carbon footprint (0.98 \%). The main proportion of this study was the same as [15]. Considering annual emission of the construction phase, the carbon footprint of project was $534.31 \mathrm{t}$ CO2e/year, which is assumed 50 years.

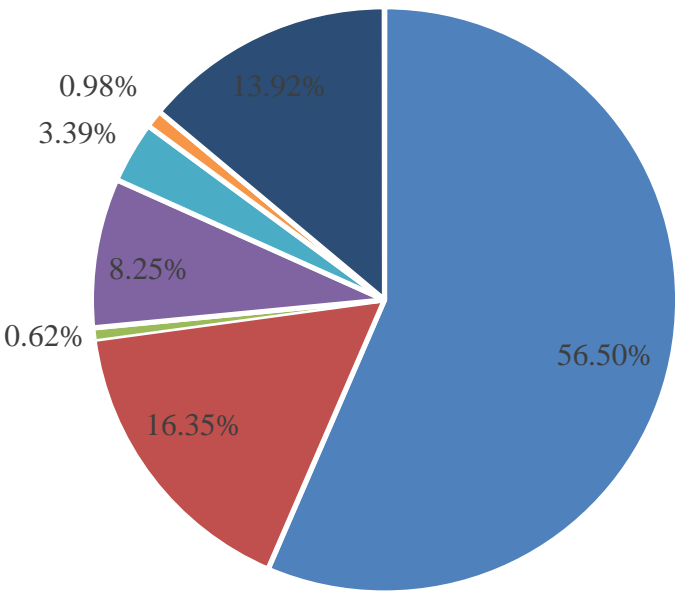

$$
\begin{aligned}
& \text { - Concrete } \\
& \text { - Group of steel } \\
& \text { - Painting } \\
& \text { - Other } \\
& \text { - Water } \\
& \text { - Electricity } \\
& \text { - Transportation }
\end{aligned}
$$

Figure 3. Proportion of greenhouse gas emissions from make-up water cooling system of construction. 
The make-up water cooling system of Bang Pakong Combined Cycle (Unit 1-2 Replacement) consists of 3 parts. Cooling tower basin has area $6,793 \mathrm{~m}^{2}$, while area of cooling water intake pump house and area of approach were $740 \mathrm{~m}^{2}$ and 3,382 $\mathrm{m}^{2}$, respectively. Carbon emissions of make-up water cooling system of study area was shown in the Table 2 . The carbon emission of cooling basin was $13,249 \mathrm{tCO}_{2} \mathrm{e}$. Due to the difference in building sizes, in order to be comparable, a square meter of floor area was used as a functional unit to quantify each building's performances. When consideration in term of area, cooling tower basin, cooling water intake pump house and approach channel were 1,950, 5,586 and 2,760 $\mathrm{CO}_{2} \mathrm{e} / \mathrm{m}^{2}$, respectively. According to literature review, there is lack the information of carbon footprint of water cooling tower in construction phase. The average of carbon emission of make-up water in this study was quite higher than Limphitakphong, et al. [15], which researched the emission of high-rise building in Thailand around 2,125 $\mathrm{CO}_{2} \mathrm{e} / \mathrm{m}^{2}$ (see Table 3).

Table 2. Carbon emissions of make-up water cooling system

\begin{tabular}{cccc}
\hline Sources & Approach channel $\left(\mathrm{tCO}_{2} \mathrm{e}\right)$ & Cooling water intake pump house $\left(\mathrm{tCO}_{2} \mathrm{e}\right)$ & Cooling tower basin $\left(\mathrm{t} \mathrm{CO}_{2} \mathrm{e}\right)$ \\
\hline Concrete & $4,351.02$ & $1,858.13$ & $8,884.27$ \\
Group of steel & $1,331.09$ & $1,104.07$ & $1,933.13$ \\
Painting & 22.94 & 2.26 & 140.59 \\
Other & 953.39 & 39.65 & $1,209.80$ \\
Water & 892.44 & 4.69 & 8.38 \\
Electricity & 87.58 & 76.09 & 97.48 \\
Transportation & $1,694.80$ & $1,048.39$ & 975.43 \\
Total & $9,333.24$ & $4,133.28$ & $13,249.08$ \\
\hline
\end{tabular}

Table 3. Embodied carbon emissions of various educational buildings

\begin{tabular}{|c|c|c|c|c|}
\hline No. & Year & Structure Type & ECI $\left(\mathrm{kgCO}_{2} \mathrm{e} / \mathrm{m}^{2}\right)$ & Ref \\
\hline 1 & 2017 & Subway Station & $1,690.0$ & [16] \\
\hline 2 & 2018 & High Rise Building & 379.9 & [15] \\
\hline 3 & 2018 & High Rise Building & 352.1 & [15] \\
\hline 4 & 2018 & High Rise Building & 295.4 & {$[15]$} \\
\hline 5 & 2020 & Approach Channel & $2,759.7$ & This study \\
\hline 6 & 2020 & Cooling Water Intake Pump House & $5,585.5$ & This study \\
\hline 7 & 2020 & Cooling Tower Basin & $1,950.4$ & This study \\
\hline
\end{tabular}

\section{Conclusion}

As the global trend, many researches studied on the design of construction for low carbon building. The carbon footprint assessment of construction of make-up water cooling system is based on B2B model. The process of construction is as a manufacturing process, while the product is buildings of make-up water cooling system. In the construction phase of this study, the total emission of make-up water cooling system of power plant was $26,715.6 \mathrm{tCO}_{2} \mathrm{e}\left(2.447 \mathrm{tCO}_{2} \mathrm{e} / \mathrm{m}^{2}\right)$. Due to service life of the power plant, these buildings release carbon footprint $534.31 \mathrm{tCO}_{2} \mathrm{e} /$ year.

For data collection, it is cannot be collected directly, including electricity, construction waste, distance, payload of transport of tools, electrical equipment and machinery. Therefore, it is necessary to refer to relevant documents such as specifications, project construction plans, purchase approval documents and research papers.

This research has limitations on carbon emission of make-up water cooling system of power plant. It is a single-case study and has potential limitations of carbon footprint of products of mechanical and electrical part of power plant construction. For improving environmental management, the other building of the power plant will be included in the next study. This first step was to enrich the database of carbon footprint of construction of power plant in Thailand. It could lead the plan and design of construction reducing environment impact in the future.

\section{Acknowledgements}

Authors would like to thank Electricity Generating Authority of Thailand (EGAT) and Italian Thai Development Public Company Limited (ITD) for providing essential information for this study. 


\section{References}

[1] Espinoza, M., N. Campo, R. Yang, H. Ozer, J. P. Aguiar-Moya, A. Baldi, L. G. Loría-Salazar, and I. L. Al-Qadi. (2019). Carbon Footprint Estimation in Road Construction: La Abundancia Florencia Case Study. Sustainability, 2019, 11(8), 2276.

[2] Thailand. (2020). Thailand third Biennial Updated Report (BUR), Office of Natural Resources and Environmental Policy and Planning.

[3] Energy Policy and Planning Office. (2015). Thailand Power Development Plan 2015-2036 (Revision 3). Ministry of Energy, Thailand.

[4] Energy Policy and Planning Office. (2018). Thailand Power Development Plan 2018-2037 (Revision 1). Ministry of Energy, Thailand (Original in Thai).

[5] TGO. (2011). Carbon Footprint Assessment Guidelines of Local Administrative Organizations, Carbon Footprint Promotion Project of Local Administrative Organizations, Thailand Greenhouse Gas Management Organization (Public Organization: TGO) (Original in Thai).

[6] TGO. (2015). Handbook of Carbon Footprint of Industrial Sector Organizations, Thailand Greenhouse Gas Management Organization (Public Organization: TGO) (Original in Thai).

[7] IPCC. (2006). 2006 IPCC Guidelines for National Greenhouse Gas Inventories, Intergovernmental Panel on Climate Change (IPCC). https://www.ipcc-nggip.iges.or.jp/public/2006gl/.

[8] ADB. (2010). Methodology for Estimating Carbon Footprint of Road Projects Case Study: India. Asian Development Bank.

[9] Wang, C. and X. Tan. (2012). Estimating Carbon Footprint in the Construction Process of a Green Educational Building, Proceedings of 2012 Int. Conf. on Construction and Real Estate Management. Kansas City, USA, 1-2/Oct. 2012, Vol. 1, pp. $175-179$.

[10] Kong, A., H. Kang, S. He, N. Li, and W. Wang. (2020). Study on the Carbon Emissions in the Whole Construction Process of Prefabricated Floor Slab. Applied Sciences, 2020, 10, 2326.

[11] Sun, H. and Y. Park. (2020). $\mathrm{CO}_{2}$ Emission Calculation Method during Construction Process for Developing BIM-Based Performance Evaluation System. Applied Sciences, 2020, 10, 5587.

[12] http://thaicarbonlabel.tgo.or.th/index.php?lang=TH\&mod=Y0hKdlpIVmpkSE5mWlcxcGMzTnBiMjQ9.

[13] http://conference.tgo.or.th/download/tgo_or_th/seminar/presentation/2010/221110/CarbonIntensity_KMUTT.pdf.

[14] SECOT. (2017). Environment Impact Assessment Report for Project or Activity which may seriously Affect Community with respect to Environmental Quality, Natural Resources and Health (Executive Summary Report) of Bang Pakong Combined Cycle (Unit 1-2 Replacement) Project, SECOT Co., Ltd. (Original in Thai).

[15] Limphitakphong, N., P. Thaipradit, P. Kanchanapiya, T. Tantisattayakul, and O. Chavalparit. (2020). Embodied Carbon Emission of Construction Materials: A Case Study of Building in Thailand, Special Issue on Science, Engineering and Environment. International Journal of GEOMATE, April, 2020, Vol. 18, Issue 68, pp. 187-193.

[16] Nithisakdiyanond, N. and J. Rukijkanpanich. (2017). Carbon Footprint Assessment of the Construction Project of the Subway Station and Tunnel. Engineering Journal Chiang Mai University, 2017, 24(2), 114-127 (Original in Thai). 